IdeAs

Idées d'Amériques

$14 \mid 2019$

Populismes dans les Amériques

\title{
Walt Whitman in His Time-And Ours
}

\author{
Kenneth M. Price
}

\section{(2) OpenEdition}

\section{Journals}

Electronic version

URL: http://journals.openedition.org/ideas/6512

DOI: 10.4000/ideas.6512

ISSN: 1950-5701

\section{Publisher}

Institut des Amériques

\section{Electronic reference}

Kenneth M. Price, " Walt Whitman in His Time-And Ours », IdeAs [Online], 14 | 2019, Online since 01 October 2019, connection on 09 November 2019. URL : http://journals.openedition.org/ideas/6512 ; DOI : 10.4000/ideas.6512

This text was automatically generated on 9 November 2019

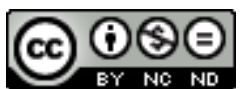

IdeAs - Idées d'Amériques est mis à disposition selon les termes de la licence Creative Commons Attribution - Pas d'Utilisation Commerciale - Pas de Modification 4.0 International. 


\title{
Walt Whitman in His Time-And Ours
}

\author{
Kenneth M. Price
}

1 What should we make of Walt Whitman and his legacy on the $200^{\text {th }}$ anniversary of his birth? There have been innumerable exhibits, conferences, readings, and celebrations in the U.S. and around the world to mark the occasion. In a way that is rare for a nineteenth-century writer, Whitman still matters to people today. What accounts for his currency, his being regularly invoked-especially in the U.S. but also internationally -in advertisements, television programs, films, and political speeches? What makes him still a living force? Crucial, of course, is what Whitman wrote, but perhaps more important is what he has come to mean through his reception and remaking across the decades and now centuries and across national borders in his extraordinary afterlives. Whitman also continues to seem fresh because "new" writings by him are located at a remarkable rate. In the past few years a stunning amount of new material has become available: a hitherto unknown novel (Jack Engle), a pseudonymously published health guide for urban men (Manly Health and Training) previously unidentified early poetry, and other writings by Whitman (letters, notebooks, art criticism, etc.). Nor is this just the purview of the scholar-the internet makes it all widely available.

2 In marking this $200^{\text {th }}$ anniversary most events have been laudatory but not entirely so. This year the North American Review has hosted online a brilliant series, "Every Atom," consisting of two hundred short annotations of Whitman's masterpiece, "Song of Myself," by poets, activists, physicists, astronomers, artists, environmentalists and others. These accounts often praise Whitman to the rooftops, but he doesn't escape sharp criticism as well. Whitman has long been thought of as a proponent of artistic, political, and sexual liberation, and when his words are inconsistent with these ends, people are prone to feel let down if not betrayed. Whitman often has been seen as one of the forefathers of American multiculturalism. As a poet who celebrated slang and language mixing, loved to imagine himself in other lands, and vowed not to discriminate, he appears like a good candidate for this position. He was also, however, a poet who gave voice to a culture that experienced slavery, genocide, and 
discriminatory policy. Whitman's meanings and legacy are receiving heightened scrutiny in the current moment of ethnic, racial, and religious intolerance.

3 A key mystery that perhaps his voluminous prose documents shed light on is how Whitman could give voice so movingly to a diverse U.S., to celebrate the teeming and varied crowds of "a nation of nations," and yet also fail to support African Americans at vital moments. He claimed he would give voice to what had long gone unexpressed:

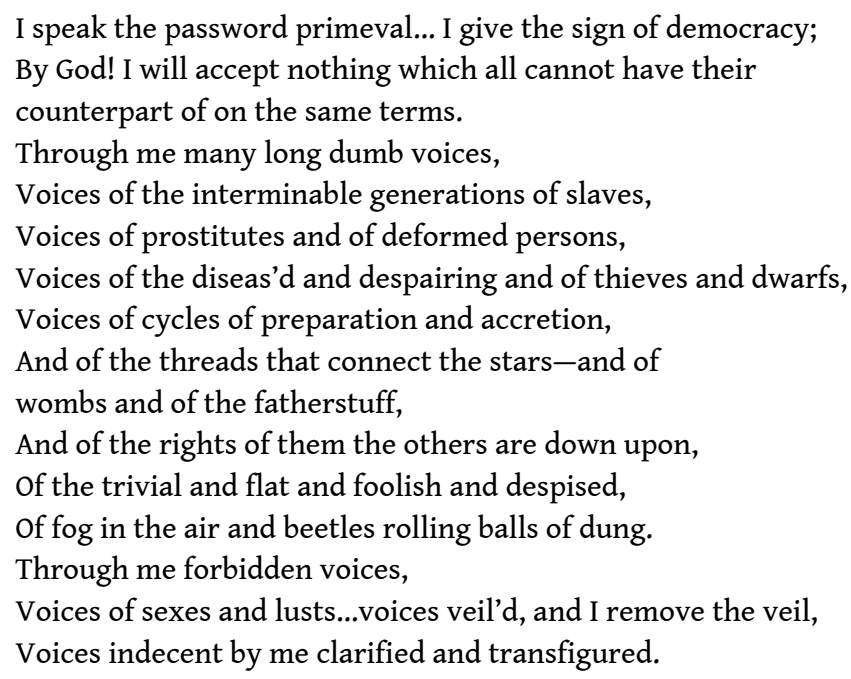

During the Civil War, Whitman collected newspaper clippings on the crucial contributions of African Americans to the Union war effort, but he never got around to poetically celebrating their achievements. Nor did he provide significant commentary on emancipation, what Charlotte Forten called "the most glorious day this nation has yet seen." Whitman was silent about the Fifteenth amendment to the U.S. Constitution, too, that right articulated in the negative-prohibiting the exclusion of voting rights on the basis of race or previous condition of servitude. Moreover, he rarely used the term Reconstruction, with its implications of radical social change. Whitman's reluctance to support black suffrage remains a disturbing aspect of his career, and it is all the more puzzling because of the importance of cross-racial sympathy in fueling his early poetic development. Whitman occasionally wished that problems he associated with African Americans would just vanish.

During the war Whitman tended mostly to white soldiers of north and south, though he assisted and consoled African American soldiers also. He remarked in Memoranda During the War (1875): "Among the black soldiers, wounded or sick, and in the contraband camps, I also took my way whenever in their neighborhood, and did what I could for them." Early in the war, when formerly enslaved people who made their way to a Union camp, they were termed "contraband of war" when Union General Benjamin Butler refused to return them to southerners demanding the return of their "property." The term "contraband" stuck, and contraband camps soon became notorious for their poverty and unsanitary conditions. A visit to contraband camps was dangerous because of the widespread disease that afflicted them. Whitman's efforts on behalf of blacks, in both contraband camps and hospitals, was warmly appreciated. In the account of his seventieth birthday celebration in With Walt Whitman in Camden, Horace Traubel mentions a "negro cook" who rushed to "embrace and shake hands" with Whitman. When asked about this encounter later, Whitman recalled going "frequently to a "hospital for negroes... at Culpepper" (Traubel H. $1964: 299$ ). 
A decade after the Civil War, Whitman noted in "Tis But Ten Years Since" (1874):

To me, the war, abdicating all its grand historical aspects, and entirely untouched by the Slavery question, revolves around these miniature pages [his hospital notebooks], and what is designated by them. They are the closest; they are not words, but magic spells. Out of them arise yet active and breathing forms. They summon up, even in this silent and vacant room as I write, not only the sinewy regiments and brigades, marching or in camp, but the countless phantoms of those who fell and were hastily buried by wholesale in the battle-pits, or whose dust and bones have been since removed to the National Cemeteries, all through Virginia and Tennessee.

7 What Whitman accomplished in caring for thousands of wounded ill, lonely, and disoriented Civil War soldiers was remarkable. Many soldiers, feeling a deep indebtedness to him, named their children after "Walt" while others remarked that he had saved their lives. Whitman's highly personalized approach yielded important results. D. Willard Bliss, the chief surgeon of Armory Square, the Civil War hospital with the highest mortality rate and where Whitman spent most of his time, asserted: "From my personal knowledge of Mr. Whitman's labors in Armory Square and other hospitals, I am of [the] opinion that no one person who assisted in the hospitals during the war accomplished so much good to the soldier and for the Government as Mr. Whitman." His work in the hospitals was an indisputably great humanitarian achievement. Nonetheless, after the fact, to mystify as "magic spells" his hospital notebooks over larger political and social change is a self-indulgent fantasy. His word "abdicating" is noteworthy since it suggests that Whitman realized that it was also his responsibility (as someone who aspired to be the national bard) to speak to the epoch-making transformation underway-more than three million enslaved people had been liberated - even as he chose to vacate that duty.

Curiously in the years after the war, his concern for African Americans gradually declined. He worked for the Attorney General's office from 1865-1873 where he primarily functioned as a clerk, but in slack times and after hours he also wrote letters to friends and family, conducted literary business, and pondered the future of democracy as he gazed through the large windows of the Treasury building in Washington, D.C. He was writing Democratic Vistas in these years, his meditation on the prospects for America, his attempt to be a sage akin to, say, Matthew Arnold and Thomas Carlyle in England. The view for Democratic Vistas was here, as he gazed out his windows facing to the south and to the west. Looking to the west, he could examine the prospect of the future: "For These States tend inland, and toward the Western sea" (Whitman W., $1860: 371$ ). Looking to the south, he could see across the river into bloodsoaked Virginia, and he could muse on the devastation of the recent Civil War and the ongoing troubles of its aftermath, including the rise of the Ku Klux Klan, a recurrent topic in the scribal letters. It is remarkable, in fact, given the prominence of the Klan in the scribal documents, that Whitman is not more forceful and direct in responding to Thomas Carlyle's racist diatribe "Shooting Niagara," a text Democratic Vistas sought to answer but ultimately failed to do. Carlyle had "lamented that a "half million excellent White men ... full of gifts and faculty, have torn and slashed one another into horrid death, ... and three million absurd Blacks, ... are completely 'emancipated'; launched into the career of improvement, likely to be "improved off the face of the earth." For Carlyle, extending the franchise in England was a bad idea, and the possibility of 
extending it to blacks in the U.S. was culturally suicidal, the equivalent of going over Niagara Falls in a barrel.

Although Whitman promised in the opening of Democratic Vistas to answer Carlyle, he never adequately did so but instead evaded the topic-another of his silences. Only in the small notes at the back of the short volume does Whitman say: "As to general suffrage, after all, since we have gone so far, the more general it is, the better. I favor the widest opening of the doors. Let the ventilation and area be wide enough, and all is safe" (Whitman W., $1871: 83$ ).This is a curious affirmation. It holds promise for women and Native Americans, not just those formerly enslaved, but rather than the rhetoric of brotherly affection that appears in Whitman's poetry about democracy, the language of opening the doors and seeking "ventilation" invokes theories about illness as caused by poverty and crowding in such places as hospitals, urban tenements, and contraband camps. His point here-all can vote safely if the country is free from the diseasebreeding conditions that are likely to infect these new voters-seems far from his own assertion in "Over the Carnage Rose Prophetic a Voice" where Whitman writes more vaguely if less conditionally, "Affection shall solve the problems of freedom."

In short, when Whitman dodged race, he could still speak the language of poetic and democratic universalism, of common adhesiveness. When he mentioned race specifically, he hedged. To many people these days, Whitman is disappointing in his treatment of race. The poet and critic Lavelle Porter has provocatively asked, "Should Walt Whitman Be \#Cancelled?" Porter's question is challenging, especially in an era newly sensitized to what some fear may be a belief in white supremacy hard wired into a significant portion of American society. Porter was responding to a 2013 incident involving a black, gay graduate student in music at Northwestern University, who refused to perform a piece of music based on Whitman's poetry because of Whitman's (not the composer's) racism. Porter says:

I hope that we can celebrate him while also telling the truth about his flaws-and America's flaws. As June Jordan says, 'I too am a descendant of Walt Whitman. And I am not by myself struggling to tell the truth about this history of so much land and so much blood, of so much that should be sacred and so much that has been desecrated and annihilated boastfully.'

11 Langston Hughes, who famously decided not to throw Leaves of Grass overboard on a journey to Africa (he discarded much else from western culture), counselled a more forgiving approach and urged us to remember the best in people, particularly in Whitman. In divisive, racially-charged times like the present, however, it is difficult to reckon honestly with the limitations of Whitman without killing off the expansive Whitman of hope and possibilities, the poet who has fueled progressive projects nationally and internationally.

Relations between persona and person are vital in Whitman's case. He grasped that in creating the "Walt Whitman" of Leaves of Grass he had forged an idealized version of himself distinct from his everyday life as Walt Whitman. Some commentators have seen the distance between person and persona as a sign of bad faith, hypocrisy, duplicity, or insincerity. But we should not regret that in his best writings he reached for more generous, more loving, and more tolerant views than those he imbibed and sometimes allowed himself to express in more hastily conceived journalism, in private jottings in notebooks, in correspondence with family members or working-class white soldiers, 
and (more rarely) blinkered moments in his poetry. To his credit, Whitman regularly strove to rise above the biases of his culture.

Interpretation of Whitman is tricky because he conflated the created character "Walt Whitman" with the real life Walt Whitman. The two co-exist often seeming to be the same person. On the other hand, there are aspects of the persona-he claims to be rude, uncouth, and the begetter of many children, for example-that do not align with the biographical person. The projected self in Whitman is always complex, ample, contradictory, and ultimately never one and the same. Brian Clements has noted:

We struggle with Whitman continually, and our grip on him shifts, just as our grip on our individual and national identities shifts. [The U.S.], like Whitman, is a great contradiction-a place of hope, yet a place of failure to provide the most basic services like health care and clean drinking water to all of our citizens; a place that holds up the rule of law as its guiding principle, yet a place of obvious quotidian injustice. If "The United States themselves are essentially the greatest poem," as Whitman asserts early in his Preface to the 1855 Leaves of Grass, then the greatest poem is both a dirty mess and a surviving promise for the possibility of renewal, justice, and reconciliation. ${ }^{2}$

The political and cultural outlook Whitman offers is alternately inspired and shortsighted, occasionally marred by an attraction to nativist politics and pseudo-scientific racial theories. Yet even as we may lament Whitman's shortcomings, we recognize his role as a rebel, an autodidact, an outsider, and the poet who insisted that the slave is equal to the master. Whitman offers a messy and complicated legacy, perhaps fit for a land that can be both disheartening and inspiring.

The United States imprisons a larger percentage of its black population than South Africa did at the height of apartheid. In the nation's capital city, Washington, D.C., approximately three out of four young black men (and nearly all those in the poorest neighborhoods) can expect to be imprisoned. What have most of us done about, say, the incarceration rate of African American males in DC or elsewhere. Our own silences and inactivity should give us pause before we become too critical of Whitman.

\section{BIBLIOGRAPHY}

Carlyle, Thomas, "Shooting Niagara-And After?”, Macmillan's Magazine, Edinburgh, Vol. XVI, April 1867.

Forten, Charlotte L, The Journals of Charlotte Forten Grimké, Brenda Stevenson (ed.), New York and Oxford, Oxford University Press, 1988.

Traubel, Horace, With Walt Whitman in Camden vol. 5 (April 8 - September 14, 1889), Gertrude Traubel (ed.), Carbondale, Illinois, Southern Illinois University Press, 1964, p. 299. Also available online: https://whitmanarchive.org/criticism/disciples/traubel/WWWic/5/whole.html Whitman, Walt, Leaves of Grass, Brooklyn, New York, 1855.

Whitman, Walt, “'Tis Ten Years Since”, New York Weekly Graphic, 24 January 1874, p. 3. 
Whitman, Walt, Memoranda During the War (Camden, NJ, 1875-1876). https:// whitmanarchive.org/published/other/memoranda.html

\section{NOTES}

1. Lavelle Porter, “Should Walt Whitman Be \#Cancelled?" JSTOR Daily, April 17, 2019.

2. Brian Clements, "Introduction," in Every Atom: reflections on Walt Whitman at 200, North American Review, May 30, 2019.

\section{AUTHOR}

\section{KENNETH M. PRICE}

Kenneth M. Price is Co-Director of the Walt Whitman Archive and Hillegass University Professor of American Literature at the University of Nebraska-Lincoln. kprice2@unl.edu 